\title{
MENCEGAH DAMPAK DARURAT KEKERASAN PADA ANAK INDONESIA
}

\author{
Nur Hidaayah \\ (Universitas Nahdlatul Ulama, Kampus A Jln. SMEA 57 Surabaya) \\ Email : nur_hidy@yahoo.co.id
}

\begin{abstract}
:
Child abuse occur in the conditions, places, people closest to where the child should feel secure that home, school and community environments. According to UNICEF that violence against children in some countries can be socially acceptable, it is allowed and is not seen as something rude. Some factors contributing to violence include: witnessing parental violence while still childhood, aggressive attitude towards the child, wife or husband, and behaved aggressively towards children and the environment that supports the violence recurs. Children who experience repeated violence much risk of adverse impacts that they showed chronic stress, including difficulties in school and problems with concentration. Things do not have to happen is depression to suicidal behavior. Help prevent the necessary co-operation of various elements of parents, educators, family leaders, community leaders, community organizations, peers, program managers across relevant sectors. Indispensable role of the academia, professional organizations, Society of Social Institutions and law enforcement officials.
\end{abstract}

Keyword: Prevent, violence, children

\begin{abstract}
Abstrak :
Tindak kekerasan pada anak banyak terjadi pada kondisi, tempat, orang terdekat di mana anak seharusnya merasa aman yaitu rumah, sekolah dan lingkungan masyarakat. Menurut UNICEF bahwa kekerasan terhadap anak di beberapa negara dapat diterima secara sosial, hal tersebut dibiarkan dan tidak dilihat sebagai sesuatu yang kasar. Beberapa faktor penyebab kekerasan meliputi : menyaksikan kekerasan orang tua saat masih usia kanak-kanak, sikap agresif terhadap anak, istri atau suami, dan berperilaku agresif terhadap anak serta lingkungan yang mendukung terjadinya tindak kekerasan berulang. Anak yang mengalami tindak kekerasan berulang banyak resiko terjadinya dampak buruk yaitu mereka menunjukkan stres kronis, termasuk kesulitan di sekolah dan masalah konsentrasi. Hal yang tidak perlu terjadi adalah perilaku depresi hingga bunuh diri. Bantuan mencegah diperlukan kerjasama berbagai elemen yaitu orangtua, pendidik, tokoh keluarga, tokoh masyarakat, organisasi masyarakat, teman sebaya, pengelola program lintas sektor terkait. Tidak lupa peran serta akademisi, organisasi profesi, LSM dan aparat penegak hukum sangat diperlukan.
\end{abstract}

Keyword : Mencegah, kekerasan, pada anak 


\section{A. PENDAHULUAN}

Seluruh anak di dunia secara terus menerus dilecehkan secara fisik maupun emosional mulai dari pembunuhan, tindakan seksual, bullying, dan penegakkan disiplin yang terlalu kasar. Tindak kekerasan banyak terjadi pada kondisi, tempat, orang terdekat di mana anak seharusnya merasa aman yaitu rumah, sekolah dan lingkungan masyarakat sekitar. Menurut UNICEF bahwa kekerasan terhadap anak di beberapa negara dapat diterima secara sosial, hal tersebut dibiarkan dan tidak dilihat sebagai sesuatu yang kasar. Korban menjadi terlalu takut untuk melaporkan kejahatan yang dialaminya, sistem hukum yang ada juga tidak bisa langsung menanggapi, lembaga perlindungan anak juga sangat sedikit (Anonym, 2012)

Negara Indonesia mencatat peristiwa kekerasan pada anak periode Mei hingga Juli 2014 yang diberitakan oleh media massa antara lain : penganiayaan Renggo oleh kakak kelasnya di Jakarta Timur, guru menghukum siswa dengan menyuruh menghabiskan belasan rokok di Gorontalo, penyiraman air keras pada Iqbal Saputra oleh pacar ibunya di Koja, sodomi pada sisiwa oleh guru di sekolah Jakarta International School, Samuel yang disiram air keras dan disuruh minum air aki oleh ibu dan ayah tirinya di Magetan (Anonym, 2014).

Beberapa faktor penyebab kekerasan meliputi : menyaksikan kekerasan orang tua saat masih usia kanak-kanak, sikap agresif terhadap anak, istri atau suami, dan berperilaku agresif terhadap anak serta lingkungan yang mendukung terjadinya tindak kekerasan berulang (Koss, Heise, \& Russo, 1994 dalam Taylor, dkk 2009).

Laporan UNICEF menyebutkan bahwa dari 190 negara hanya ada 39 negara di seluruh dunia yang memiliki perlindungan anak-anak secara hukum. UNICEF menyatakan, 1 dari 10 anak perempuan di dunia mengalami pelecehan seksual. Sementara, 6 dari 10 anak (1 miliar) di seluruh dunia, mengalami kekerasan fisik di usia 2-14 tahun. Laporan kekerasan pada anak yang masuk ke Komnas PA didominasi kejahatan seksual yang dari 2010 hingga 2014 angkanya berkisar 42$62 \%$. Pantauan tersebut merupakan sebagian kecil kasus yang menimpa anak-anak Indonesia, mengingat penduduk Indonesia menurut Badan Pusat Statistik (BPS) pada tahun 2011 adalah 237.641.326 jiwa, dengan menduduki peringkat ke empat dengan jumlah penduduk terbesar di dunia di bawah RRC, India dan Amerika Serikat. Menurut data dari KPAI, sekitar 40.000 anak mengalami eksploitasi seksual baik karena korban trafiking maupun dilacurkan, sekita 2,5 juta anak korban kekerasan fisik, psikis, seksual maupun sosial, dan 4,5 juta anak diperkejakan serta sebanyak 3 juta anak melakukan pekerjaan berbahaya (Imelia Pebreyanti, 2014).

Menurut pantauan dari Komnas Perlindungan Anak Indonesia (KPAI) pada tahun 2011 saja telah terjadi 2.275 kasus, yang diantaranya 887 kasus seksual. Lalu KPAI juga memantau pada tahun 2012 kekerasan terhadap anak telah terjadi 3.871 kasus, yang diantaranya 1.028 merupakan kekerasan seksual terhadap anak. Sedangkan tahun 2013 selama bulan Januari-Februari, KPAI memantau sebanyak 919 telah terjadi kasus kekerasan terhadap anak, yang diantaranya 216 kasus yang terjadi merupakan kekerasan seksual (Imelia Pebreyanti, 2014).

Anak yang dianiaya mengalami banyak resiko yaitu mereka menunjukkan stres kronis, termasuk kesulitan di sekolah dan masalah 
konsentrasi. Hal yang tidak perlu terjadi adalah perilaku depresi hingga bunuh diri. Bahkan paling buruk terjadi di sepanjang hidup anak hingga dewasa, mereka terbiasa menjadi penganiaya pula (Taylor, Shelley E., Peplau, Letitia Anne \& Sears, David O, 2009).

Dampak yang dialami anak adalah merasa ketakutan, kebingungan, dan kaget melihat kekerasan yang terjadi pada orangtuanya; (2) Tumbuh perasaan bersalah karena menganggap diri menjadi penyebab munculnya kekerasan; (3) Menjadi rewel, mengeluh sakit, sulit tidur, dan kembali berperilaku seperti bayi (mengisap jempol, mengompol, berbicara menggunakan bahasa bayi atau cadel, selalu minta digendong atau ditemani); (4) Cenderung suka melawan dan kasar atau malah justru menjadi tidak mau berteman dan lebih memilih menyendiri; (5) Jika hal tersebut dibiarkan terus, kemungkinan bisa mengganggu perkembangan anak, baik secara fisik, kejiwaan, perilaku, maupun prestasinya nanti; (6) Dampak jangka panjang pada anak laki-laki adalah meniru perilaku kekerasan yang dilakukan oleh ayahnya. Sedangkan anak perempuan cenderung menerima kekerasan sebagai suatu hal yang wajar sehingga ketika dewasa nanti besar kemungkinan akan kembali menjadi korban (Redaksi koran pendidikan, 2013)

Pentingnya kerjasama antara berbagai pihak agar dapat mengurangi darurat kekerasan pada anak di Indonesia. Keterlibatan pihak yang dimaksud adalah keluarga yang mengasuh anak, juga lembaga pendidikan, tenaga kesehatan dan tokoh agama dalam mencegah dan menangani dampak kekerasan pada anak. Keterlibatan masyarakat dan komisi perlindungan anak sebagai penyedia lingkungan aman dan nyaman bagi anak, dan terakhir pemerintah sebagai pembuat kebijakan dalam bentuk Undang-undang perlindungan anak serta aparat penegak hukum sebagai pelaksana perlindungan terhadap keamanan warga negara. Berbagai pihak tersebut harus saling mendukung dalam menjalankan tugas dan fungsinya masing-masing demi terpenuhinya hak anak bebas dari tindak kekerasan.

\section{B. PEMBAHASAN}

\section{Pengertian}

Kekerasan pada anak atau child abuse and neglec yaitu semua tindakan fisik, mental dan seksual dari orangtua atau pengasuh di setiap keadaan yang menunjukkan kurangnya perawatan dan perlindungan terhadap anak, sehingga menyebabkan luka dan kegagalan perkembangan baik fisik, intelektual, mental dan sosial. Contoh tindakan kekerasan pada anak adalah pemukulan, penyerangan fisik berkalikali sampai terjadi luka, eksploitasi (pornografi, penyerangan seksual, pemberian makanan yang tidak layak atau kurang gizi, pengabaian pendidikan dan kesehatan. Menurut UU perlindungan anak pasal 13 yang dimaksud kekerasan terhadap anak adalah deskriminasi, eksploitasi baik fisik maupun seksual, penelantaran, kekejaman, kekerasan seksual dan penganiayaan, ketidakadilan dan perlakuan salah lainnya.

\section{Pelaku Tindak Kekerasan}

Menurut BPS (2006)

menyatakan bahwa pelaku kekerasan ternyata orang yang semestinya menjadi pembimbing, pelindung, penerima pengaduan, pemberi rasa aman dan kasih sayang. Berikut ini tabel tentang pelaku kekerasan secara berurutan : 
Tabel. Pelaku Kekerasan Terhadap Anak (\%) (Permeneg PP dan PA RI, 2011)

\begin{tabular}{|l|c|c|c|}
\hline \multicolumn{1}{|c|}{ Pelaku } & Perkotaan & Pedesaan & $\begin{array}{c}\text { Total/ } \\
\text { rata- } \\
\text { rata }\end{array}$ \\
\hline Orangtua & 56,5 & 64,6 & 61,4 \\
\hline Lainnya & 26,8 & 21,9 & 23,9 \\
\hline Tetangga & 8 & 5,8 & 6,7 \\
\hline Guru & 2,8 & 3,1 & 3 \\
\hline $\begin{array}{l}\text { Famili } \\
\text { (saudara) }\end{array}$ & 4,1 & 3,6 & 3,8 \\
\hline $\begin{array}{l}\text { Rekan } \\
\text { kerja }\end{array}$ & 0,9 & 0,7 & 0,8 \\
\hline Majikan & 0,8 & 0,1 & 0,4 \\
\hline
\end{tabular}

\section{Penyebab}

Kekerasan terjadi apabila seseorang menggunakan kekuatan, kekuasaan dan posisinya untuk menyakiti orang lain dengan sengaja bukan karena kebetulan. Beberapa faktor penyebab kekerasan meliputi : menyaksikan kekerasan orang tua saat masih usia kanak-kanak, sikap agresif terhadap anak, istri atau suami, dan berperilaku agresif terhadap anak serta lingkungan yang mendukung terjadinya tindak kekerasan berulang (Koss, Heise, \& Russo, 1994 dalam Taylor, dkk 2009).

\section{Klasifikasi}

Menurut Terry E. Lawson menyatakan bahwa kekerasan pada anak digolongkan menjadi 4 macam, yaitu (Rochmat Wahab, 2013):

\section{a. Emotional abuse}

Yaitu tidak adanya perhatian maupun respon orangtua setelah anak memintanya. Pengabaian ini akan diingat seterusnya oleh anak bila kekerasan ini berkelanjutan. Gejala yang ditunjukkan oleh anak karena mendapatkan kekerasan ini adalah perilaku maladaptif (menarik diri, pemalu, menangis jika didekati, takut keluar rumah dan takut bertemu orang lain.

\section{b. Verbal abuse}

Kekerasan berupa bentakan, kata kasar, makian orangtua terhadap anak. Anak akan mengingat kekerasan ini jika berlangsung dalam satu periode.

\section{c. Physical abuse}

Kekerasan berupa pukulan dengan dan tanpa benda tertentu yang mengakibatkan luka fisik pada anak. Pemicunya adalah minta jajan, buang air, atau muntah di sembarang tempat, memecah barang berharga. Kekerasan ini akan diingat anak bila pukulan tersebut meninggalkan bekas atau luka.

\section{d. Sexual abuse}

Kekerasan berupa perlakuan orang yang lebih besar melalui kata, sentuhan, gambar visual secara langsung. Biasanya hal ini terjadi kurang maupun selama 18 bulan pertama dalam kehidupan anak. Kekerasan ini dapat berupa memperlihatkan buku, gambar atau film porno pada anak.

\section{Akibat}

Semua kekerasan yang diterima anak terekam dalam alam bawah sadar hingga masa dewasa dan seterusnya sepanjang hidup. Anak korban kekerasan akan melakukan hal yang sama yang diterimanya sewaktu kecil, di usia dewasa. Mereka akan lebih agresif dalam melakuan kekerasan serupa terhadap anak-anak. Penjelasan lengkap tentang akibat yang dialami anak dapat diurutkan berdasarkan tahap perkembangannya, sebagai berikut (Rochmat Wahab, 2013) : 
a. Usia bayi (0 sampai 1 tahun)

Usia bayi seringkali menunjukkan keterbatasannya dalam kaitannya dengan kemampuan kognitif dan beradaptasi. Jaffe dkk (1990) menyatakan bahwa bayi yang menyaksikan kekerasan yang dilakukan orangtuanya, sering memiliki kesehatan yang buruk, kebiasaan tidur yang jelek, dan teriakan yang berlebihan. Keadaan ini berkonsekuensi logis pada gangguan pertumbuhan dan perkembangan baik fisik maupun emosi, juga banyak terjadi tidak lancarnya komunikasi.

b. Usia anak todler (1 sampai 3 tahun)

Amarah verbal yang disertai serangan fisik dapat mengancam rasa aman anak secara sosial. Pada masa selanjutnya sikap yang akan ditunjukkan anak adalah agresif terhadap teman sebayanya. Anak laki-laki cenderung lebih agresif daripada anak perempuan selama simulasi, sebaliknya anak perempuan lebih mengalami stress. Dampak kekerasan terhadap anak usia todler ini sering digambarkan dengan problem perilaku, seperti seringnya sakit, memiliki rasa malu yang serius, memiliki self-esteem yang rendah, dan memiliki masalah selama dalam pengasuhan, terutama masalah sosial, misalnya: memukul, menggigit, dan suka mendebat.

c. Usia prasekolah (3 sampai 5 tahun)

Cumming (1981) melakukan penelitian tentang KDRT terhadap anak-anak yang berusia TK, pra sekolah, sekitar 5 atau 6 tahun. Dilaporkannya bahwa anak yang stres pada usia sebelumnya dapat diidentifikasi tiga tipe reaksi perilaku. Pertama, 46\%-nya menunjukkan emosi negatif yang diwujudkan dengan perilaku marah yang diikuti setelahnya dengan rasa sedih dan berkeinginan untuk menghalangi atau campur tangan. Kedua, 17\%-nya tidak menunjukkan emosi, tetapi setelah itu mereka marah. Ketiga, lebih dari sepertiganya, menunjukkan perasaan emosional yang tinggi (baik positif maupun negatif) selama berargumentasi. Keempat, mereka bahagia, tetapi sebagian besar di antara mereka cenderung menunjukkan sikap agresif secara fisik dan verbal terhadap teman sebayanya. Berdasarkan pemeriksaan terhadap 77 anak, Davis dan Carlson (1987) menemukan anak TK yang menunjukkan perilaku reaksi agresif dan kesulitan makan pada pria lebih banyak terjadi daripada wanita.

Hughes (1988) melakukan kelompok yang menyaksikan kekerasan menunjukkan tingkat stres jauh lebih tinggi, dan kelompok anak usia pra sekolah menunjukkan perilaku stres yang lebih tinggi daripada anak usia todler. deLange (1986) melalui pengamatannya bahwa kekerasan berdampak terhadap kompetensi perkembangan sosial-kognitif anak usia prasekolah. Ini dapat dijelaskan bahwa anak-anak prasekolah yang dipisahkan secara sosial dari teman sebayanya, bahkan tidak berkesempatan untuk beradaptasi dengan kegiatan atau minat teman sebayanya juga. Mereka cenderung memiliki beberapa 
masalah yang terkait dengan orang dewasa.

\section{d. Usia Sekolah (7 sampai 12 tahun)}

Jaffe dkk (1990) menyatakan bahwa pada usia SD, anak yang menyaksikan KDRT, secara cepat belajar bahwa kekerasan adalah suatu cara yang paling tepat untuk menyelsaikan konflik dalam hubungan kemanusiaan. Mereka lebih mampu, mengekspresikan ketakutan dan kecemasannya berkenaan dengan perilaku orangtuanya.

Hughes (1986) menemukan bahwa anak usia sekolah kesulitan terhadap pekerjaan sekolah, prestasi akademik buruk, tidak suka sekolah, dan kesulitan konsentrasi. Wolfe et.al, 1986: Jaffe et.al, 1986, Christopoulus et al, 1987 menguatkan melalui studinya, bahwa anak dari keluarga yang mengalami kekerasan domistik cenderung memiliki problem prilaku lebih banyak dan kompetensi sosialnya lebih rendah daripada keluarga yang tidak mengalami kekerasan dalam rumah tangga.

Sementara studi yang dilakukan terhadap anak Australia, (Mathias et.al, 1995) sebanyak 22 anak dari usia 6 sd 11 tahun menunjukkan bahwa kelompok anak-anak yang secara historis mengalami kekerasan dalam rumah tangganya cenderung mengalami problem perilaku pada tinggi batas ambang sampai tingkat berat, memiliki kecakapan adaptif di bawah rata-rata, 11 memiliki kemampuan membaca di bawah usia kronologisnya, dan memiliki kecemasan pada tingkat menengah sampai dengan tingkat tinggi. e. Usia remaja (13 sampai 21 tahun)

Usia remaja telah memiliki kesadaran bahwa ada cara-cara yang berbeda dalam berpikir, merasa, dan berperilaku dalam kehidupan di dunia ini. Misalnya studi Davis dan Carlson (1987) menyimpulkan bahwa hidup dalam keluarga yang penuh kekerasan dapat meningkatkan kemungkinan menjadikan isteri yang tersiksa, sementara itu Hughes dan Barad (1983) mengemukakan dari hasil studinya bahwa angka kejadian kekerasan yang tinggi dalam keluarga yang dilakukan oleh ayah cenderung dapat menimulkan korban kekerasan, terutama anakanaknya. Tetapi ditekankan pula oleh Rosenbaum dan O'Leary (1981) bahwa tidak semua anak yang hidup kesehariannya dalam hubungan yang penuh kekerasan akan mengulangi pengalaman itu. Artinya bahwa seberat apapun kekerasan yang ada dalam rumah tangga, tidak sepenuhnya kekerasan itu berdampak negatif kepada semua anak remaja, tergantung ketahanan mental dan kekuatan pribadi remaja tersebut.

Dari banyak penelitian menunjukkan bahwa konflik antar kedua orangtua yang disaksikan oleh anak-anaknya yang sudah remaja cenderung berdampak yang sangat berarti, terutama anak remaja pria cenderung lebih agresif, sebaliknya remaja wanita cenderung lebih dipresif (Rochmat Wahab, 2013).

Menurut Pedoman

Penggolongan Diagnostik Gangguan Jiwa III yang merupakan kriteria gangguan stres pasca-trauma (post traumatic stres disorder atau PTSD) yang dapat dialami anak yaitu : 
a. Kejadian timbul dalam kurun waktu 6 bulan setelah peristiwa traumatik berat.

b. Terdapat penghayatan berulang, bayang-bayang atau mimpi dari kejadian traumatik tersebut secara berulang-ulang (flash back).

c. Gangguan otonomik, gangguan efek dan kelainan perilaku seperti : Hyperarousal, dengan gejala : agresif, insomnia, reaksi emosional yang intens (depresi dengan keinginan bunuh diri), merupakan indikasi bahaya menerus. Intrusion, dengan gejala : mimpi buruk, ingat peristiwa mencekam dan trauma. Numbing (mati rasa) dengan gejala : merasa terkucilkan, tidak diperhatikan.

d. Minggu sampai bulan selanjutnya, anak yang menjadi korban dinggapi ketakutan berat menjadi hamil atau terkena penyakit kelamin, takut kekerasan fisik dan kematian, tkut kerumunan orang banyak, takut didekati dari belakang, takut berhubungan seksual meskipun dengan suami dan bahkan takut pada sesuatu yang sulit diduga.

\section{Cara mencegah}

Pencegahan adalah tindakan yang dilakukan untuk menghilangkan berbagai faktor yang menyebabkan melestarikan segala bentuk kekerasan terhadap anak. Sebelum menjelaskan cara mencegah, terlebih dahulu mengetahui beberapa pelaku yang bisa membantu mencegah darurat kekerasan. Pelaku pencegah kekerasan dapat dibagi menjadi 2 (dua) yaitu langsung dan tidak langsung. Sasaran pelaku pencegah langsung adalah pendidik, orangtua, tokoh keluarga, tokoh masyarakat, organisasi masyarakat, teman sebaya, pengelola program lintas sektor terkait. Sedangkan pelaku pencegah tidak langsung adalah akademisi, organisasi profesi, LSM dan aparat penegak hukum. Strategi upaya pencegahan, sebagai berikut (Permeneg PP dan PA RI, 2011) :

a. Penyusunan media KIE (Komunikasi Informasi Edukasi) tentang upaya pencegahan kekerasan terhadap keluarga, masyarakat dan lembaga pendidikan.

b. Penggalangan peran serta berbagai media komunikasi dalam penyebarluasan media KIE tentang pencegahan kekerasan terhadap anak.

c. Peningkatan peran serta lembaga pemerintah, masyarakat, keagamaan dan dunia usaha dalam optimalisasi pencegahan kekerasan terhadap anak di lingkungan masyarakat dan lingkungan pendidikan.

d. Pemanfaatan rumah ibadah, institusi pendidikan formal dan non formal sebagai wadah sosialisasi mengenai dampak kekerasan pada anak di lingkungan keluarga, masyarakat dan lingkungan pendidikan.

e. Pemberdayaan keluarga dalam kegiatan program pencegahan kekerasan pada anak.

f. Penguatan kemampuan teman sebaya (peer group) sebagai agen perubah dalam mengurangi akibat kekerasan pada anak di lingkungan masyarakat dan lingkungan pendidikan.

g. Pemanfaatan forum-forum anak yang ada di semua wilayah.

h. Pengawasan dan monitoring berbagai program pencegahan di lingkungan keluarga, masyarakat dan lingkungan pendidikan.

i. Meningkatkan upaya pencegahan kekerasan pada anak melalui program UKS (Unit Kesehatan Sekolah). 
j. Penggalangan peran serta berbagai media komunikasi dalam penyebar luasan informasi.

\section{SIMPULAN}

1. Menurut UU perlindungan anak pasal 13 yang dimaksud kekerasan terhadap anak adalah deskriminasi, eksploitasi baik fisik maupun seksual, penelantaran, kekejaman, kekerasan seksual dan penganiayaan, ketidakadilan dan perlakuan salah lainnya.

2. pelaku kekerasan ternyata orang yang semestinya menjadi pembimbing, pelindung, penerima pengaduan, pemberi rasa aman dan kasih sayang.

3. Semua kekerasan yang diterima anak terekam dalam alam bawah sadar hingga masa dewasa dan seterusnya sepanjang hidup.

4. Pencegahan adalah tindakan yang dilakukan untuk menghilangkan berbagai faktor yang menyebabkan melestarikan segala bentuk kekerasan terhadap anak. Peran serta pendidik, orangtua, tokoh keluarga, tokoh masyarakat, organisasi masyarakat, teman sebaya, pengelola program lintas sektor terkait, akademisi, organisasi profesi, LSM dan aparat penegak hukum melalui penyusunan media KIE (Komunikasi Informasi Edukasi) tentang upaya pencegahan kekerasan.

\section{DAFTAR RUJUKAN}

Anonym (2012). Kekerasan Terhadap Anak. http://www.liputan6.com/ tag/kekerasan-terhadap-anak "\#Kekerasan Terhadap Anak". Diakses tanggal 7 Januari 2015.
Anonym, (2014). Indonesia Darurat Kekerasan Pada Anak. http://nasional.kompas.com/read/2 014/05/07/0527140/Indonesia.Dar urat.Kekerasan.pada.Anak. Diakses tanggal 9 Januari 2015.

Imelia Pebreyanti (2014). Unicef 1 dari 10 Anak Perempuan Alami Pelecehan Seksual. http://news.liputan6.com/read/210 1694/unicef-1-dari-10-anak-perem puan-alami-pelecehan-seksual diakses tanggal 7 Januari 2015.

Permeneg PP dan PA RI no. 6 tahun 2011. Panduan Pencegahan KTA di Lingkungan Keluarga, Masyarakat dan Lembaga Pendidikan.

Rochmat Wahab (2013). Kekerasan Dalam Rumah Tangga: Perspektif Psikologis dan Edukatif. Staff.uny.ac.id/dosen/prof-drrochmat-wahab-mpd-ma. Diakses tanggal 07 Januari 2014.

Taylor, Shelley E., Peplau, Letitia Anne \& Sears, David O. (2009). Psikologi Sosial edisi 12. Jakarta: Kencana. 